\title{
WOMEN OF POWER COMPARED IN THE CELTIC AND SLAVIC TRADITIONS DEAN MILLER
}

\section{Introduction}

This will be a brief and tentative effort at comparison that may begin with thematic resemblances, but will attempt to move past these parallels to find deeper ideological (in the Dumézilian sense) roots. That is, I will try to find and found my comparands in an Indo-European patterning matrix or common ancestry, despite the obvious geographical or spatial separation (at least at the present time) of the two cultural-linguistic traditions we have in primary view. To take up "women of power" in the Celtic and the Slavic contexts also confronts a pseudo-historical cliché with some historically factual backing: that is, the essentially "patriarchal" conformation (or essential character) of the I-E sociopolitical order, where male rulers and warriors are said to dominate, worshiping, aided by or associated with potent (male) deities. This view is, I think, much too simplistic or at least un-nuanced, and I hope to show that in the brief account and comparative analytic attempt that follows.

I am also taking a multiform view of what "power" signifies here, from power defined as the simple statement of overlordship or domination by force or threat of force, to the potent, overt manipulation of symbols, to more subtle and indirect hints of potentia, and with a complex (or occluded) religious imagery also brought into view; we will be not only be searching "on the ground" (or even in the ground) but looking upward as well, toward transcendent and barely circumscribable (that is, supernatural or divine) powers and their various personifications.

\section{The Celtic Imagination}

If we concentrate on the Western Celtic ancient and medieval evidence - that is, on evidence from Gaul, Ireland, and Wales - we will see an accumulation of data that is either deprived of any clear intellectual context (I refer to archeological finds, setting aside the small amount of paleographic inscription revealed or uncovered to date) or is anachronistic, being heavily censored by or filtered through sources, witnesses, narratives or other documents representing an inimical (or at least a very different) thoughtworld as compared to the pagan context under examination. What, especially, the triumphant Christian faith and its misionaries, priests, bishops and pious observers thought of the pre-Patrician religious structure in Ireland, and the myths and tales in which this structure was presented, for example, is visible in the rather confused or, we assume, cleansed and censored versions left to us (though in fact there could be some accommodation). How did they see, and how did they describe, an undoubtedly feminine potency in the tales and fragments of myth they have passed on and repeated for us? (Putting aside foor now the simple transmogrification of a female Celtic deity into Christian sainthood - Bridgit, clearly, would be an example).

Taking up the image of Medb, who is especially important to the great Táin Bó Cúailnge, we can see the clerical attitude reflected in the view that Medb of Connacht was simply a "promiscuous Celtic queen" (with her long list of royal mates or consorts) while in fact she clearly was an ancient personification of Sovereignty - for, as Máire 
Herbert tells us "In early Ireland women were not sovereigns, but sovereignty itself was conceived of as female" (Herbert 1992: 264). "Marriage to sovereignty" (in all its manifestations) is indeed a big Celtic theme, though it is closely related to the hieros gamos we can discover in a variety of other cultures, and we will also find a close and complex connection to another important theme, and that is the collocation of images around the figure of the horse, and, more, of the horse-goddess.

Supposedly (again) the horse attends and stands as a marker for that aggressive, transgressive, hyper-masculine warrior culture that, in this theory carried Indo-European values with it, extending from the Indic Ärya to the greatest of the Celtic charioteerheroes. In fact, as Jaan Puhvel contended some years ago in his emblematic essay, "Aspects of Equine Functionality," the horse has long transported (as well as its rider or the charioteer) a heavy load of multiplied and potent signs and symbols, and in terms of the Dumézilian trifunctional theory, can easily be assigned to any of the three canonical Functions (Puhvel 1970), from the sovereign theory and operation, to the warrior's art, to the Function of fertility and increase (Puhvel 1987: Chapter 15).

And here we see the "powerful" feminine emerging, in the Celtic context, as a serious co-sign with the horse, and in various modalities: the euhemerized horse-goddess Rhiannon is an important player in the Welsh Mabinogi (specifically in Pwyll Pendefig Dyfed and Manawydan fab Llyr), the cult of the widely attested horse-goddess Epona is prominent in Gaul (she also has some maternal and fertility reflexes: see Green 1986: 91-94, 171-5), while even the Irish Medb, despite her association with the great Raid and the Bull of Cooley, has (as Puhvel acutely notes) close ties to the horse-cult (Puhvel 1970: 261). Even the historical instance of a female ruler (albeit a temporary one), the rebel-queen Boudicca of the Iceni in Britain, saw her as an iconic chariot-rider. ${ }^{1}$ As is normal in the pagan Celtic context, to identify and to clearly categorize the great variety of deities and semi-divine figures is not an easy task - Claude Sterckx caught the essentiality of the problem in the title of his Les dieux protéens des Celtes et des IndoEuropéens (Sterckx 1996). Puhvel, at least at one time, accepted the idea of an "omnifunctional goddess" who could operate in all three of the Dumézilian Fonctions, and Emily Lyle has explored this possibility as well (Lyle 1982). It is even possible that the "feminine" aspect or affect of power can be assigned to another functional category entirely, as N. J. Allen has suggested a fourth (and in fact a fifth) function, exterior to or added to the canonical three associated with Dumézil's theoretical construction (e.g., Allen 1987, 1993, and see Miller 1999).

Even as we continue to examine the concept of Sovereignty in its Celtic feminine dimension, we meet complications; in fact, we can set up a sort of continuum of effective potency in both fictional/mythical figures and historical personages, extending from someone like Bronwen (in the Welsh Mabinogi Branwen ferch Llyr), through unpredictable, perverse and dangerous war-goddesses such as the Irish Morrigu, to an actual war-queen such as Boudicca. ${ }^{2}$ Branwen is, no doubt, a reflex of the Sovereignty

\footnotetext{
${ }^{1}$ Tacitus, Ann. xiv.35: Boudicca curru filias prae se vehens. Maier notes the discovery, in Gaul, of an altar dedicated to a goddess called Boudicca, but the nature and the cult-site of this divinity is unknown, though probably it was North British (Maier 1997: 42).

${ }^{2}$ Green (1986: 73) adds, as an exemplary British war-queen, Cartimandua of the Brigantes, but neither Tacitus nor other, later - modern - commentators make much of her warlike stance: Tacitus (Ann. XII.40) says that the tribesmen were "stung with shame at the prospect of being under the dominion of a woman" while both Mommsen (1887: 198) and Petit (1976: 32) show her as friendly to the Roman power. One
} 
Goddess (that is, marriage to her authenticates or confers kingly sovereignty), but (as Patrick Ford has observed) she is a rather passive figure as compared to Rhiannon and especially to the lively, outspoken, and autocratic Medb (I could suggest that Branwen has thematic and affective mythic affinities to Helen of Troy) (Ford 1977: 60; Miller 2006). The Morrigu herself is a complex figure, best known for her final triumph over the dominant Ulster hero Cú Chulainn, but who also has a large, supportive part in the mythic battles of the Tuatha Dé Danann and their foes. As for Boudicca, it is of interest (though it evades explanation for now) that within the Celtic realm Britain could see a genuine war-queen, but ancient Ireland would not, nor would Gaul, so far as I am aware.

Finally, it should be remarked that the Marriage to Sovereignty theme, and the notion of the Celtic horse-goddess, are or can be further complicated, so Geraldus Cambrensis provides us with a notorious case of what Sterckx calls an "étonnante" occurence:

“...elle d'une copulation entre le roi et son royaume réprésenté par une jument ou, apres une inversion significative, entre un étalon et la reine." (Sterckx 2004: 52).

This "barbarous and abominable" (and perhaps but not certainly fictitious) royal ritual in Northern Ulster has, as it happens, a close if not precise parallel, to the ancient Vedic horse-sacrifice (aśvamedha) and to a recorded Gaulish ceremony as well (see Puhvel 1955; 1987: 269-276). The "marriage between king and realm" thus may take many strange forms in the Celtic thoughtworld, some of them reconnecting to the horse as a particularly iconic animal morphism. ${ }^{3}$

\section{The Slavic Pattern}

It is perhaps too easy to see a singular symmetry of reversal between the Celtic evidence and the Slavic, for, if we take Herbert's dictum concerning Irish signs or indicators of sovereignty as compare to actual female sovereigns or rulers, the Slavic data seems to show the opposite: we have no clearly apparent mythic figures who "marry" the king and thus confer sovereignty (but see my remarks on Olga, below), and yet we have a significant amount of evidence of, and citations for, female rulership in the Slavic lands (my best example will refer specifically to this Kievan Grand Princess Olga). Setting that pattern aside for the moment, the Slavic material is in its own way perversely presented, with plenty of hints regarding feminine potencies, but little of the overt mythic and dramatic personifications and narrative examples found in the tales emanating from the Western Celtic lands and contexts. In the murky sphere of religious cult and practice, even the names of West and East Slavic pagan deities are not fully known, and when they are known, their identifiable range of "function," power or competence often is unclear

might remark, if only for informational purposes, that all of these latter scholars are male - as was Tacitus, for that matter.

3 The "sovereignty-conferring" female formed as a hag or as a monster is also known; see e.g. the monstrous ancestry of the mate of Airt, Delbchaem, who became the mother of the "perfect king," Cormac mac Airt (Ó Cathasaigh 1977: 26-29). 
(though in itself our ignorance or gnosis rather parallels the Celtic evidence we have accumulated, with its collectivity of notoriously "protean" gods and goddesses). ${ }^{4}$

Some assistance so far as the Slavic situation is concerned comes to us from the closely-related Baltic language group and cultural environment. Here it is important to recall that Christianity reached the Baltic area quite late, and it is even more important to recall that in the late $13^{\text {th }}-14^{\text {th }}$ centuries the Grand Dukes of Lithuania officially resuscitated paganism and re-established a pagan cult, three centuries after Kievan Rus was converted to Christianity and the East Slavs generally came under either Roman (Western, papal) or Constantinopolitan (Eastern, and imperial) missionary and ecclesiastical influence. A pagan 'fire temple' devoted to the god Perkunas, and located in Vilnius, was attested to by various authors and was identified with the relifious inclinations of pagan Lithuania's Grand Duke Gediminas; this cult was long doubted, until just such a site was found during excavations under the Vilnius cathedral in the 1930s (Rowell 1991: 132-137, see fig. 4 on p. 136). ${ }^{5}$ Some sort of reflex of an IndoIranian fire-cult certainly seems possible here, though we see no multiplicity of deities worshiped, only one. Then again, a striking feature of what we know of LithuanianBaltic religion (encased or encrypted in funerary ritual) was revealed at the pagan Gediminas's funeral, which was accompanied by human sacrifice and specifically by a sacrifice by burning, the victim being enclosed in a wooden or wicker structure that very much resembles the "wickerman" figures described by Julius Caesar in Gaul, also used, by the druids, in sacrificial ritual ( $B G$ vi.16.). But, other than the fairly obvious parallel between Baltic Perkunas and East Slavic Perun (as they would be identified as Jovian thunder-gods, cognate to Celtic Taranis?) we don't know much more about pagan Lithuania's divinities, merely possessing a number of fragments and hints (of course again - all filtered through Christian sources that are highly, and predictably, critical of any residual pagan practice). And no feminine deity of any eminence is visible here in the Baltic context, though the folkloric evidence certainly shows plenty of female potencies - personified spirits, or 'fairies,' - whose connection with the goddesses of what Marija Gimbutas called Old Europe can at least be claimed (see Dexter 1990: 5360, Gimbutas 1974/1982). ${ }^{6}$

The situation in respect to the East Slavs adjacent to the Baltic peoples is roughly the same, though we at least have the names of gods and - finally - a feminine presence is identified on the list. Our source here is the Povest'Vremennykh Let (in English called The Russian Primary Chronicle) which provides us with at least some knowledge - some names - of the East Slav pantheon at the time of the conversion of the Rus' to Christianity (the Povest' gives us the most extraordinary range of information, from the precise details, clause by clause, on the $10^{\text {th }}$ century trade-treaties made with the Byzantines, to the wildest and most efusive and florescent narratives based on folklore

\footnotetext{
${ }^{4}$ About a Baltic society closely related to the Slav Puhvel noted that its "non-literate character resembled that of ancient Gaul" (Puhvel 1987: 223).

${ }^{5}$ Gediminas also seems to have instituted a form of priesthood more or less in imitation of the Christian practice, and a single "fire-god" (if that is what is seen here) as a center of cult would appear to be a similar imitation; we might discern a parallel to the pagan "monotheism" established by the emperor Julian, in the $4^{\text {th }}$ century C.E.

${ }^{6}$ Here I should note the specific comparison, undertaken by Professor Mikhailova, of a Celtic and a Slavic "spirit" of a special type, that is, the Irish banshee and the Russian rusalka, as the revealer of destiny or fate, see Mikhailova 2005.
} 
and legend - in other words, it is a typical medieval chronicle). The listing of Slavic deities found here has been interpreted variously - at least one attempt to assign a trifunctional value to them was made, early on, by V. N. Toporov (1961), and a fairly recent analysis by Puhvel seems to take the position that the listing in the Povest' includes deities borrowed, it would seem, willy-nilly from Indo-Iranian sources (he cites the "god" Khors, from the name of a Persian solar deity, and Simarglu, from the legendary Persian Simorg, a mythic "wonder-bird" (Puhvel 1987: 233). This scholar also notes the ambiguous absence of a Slavic god who is well known elsewhere, and that is Volos or Veles, a god of animal fertility and abundance (who shows up earlier in the Povest' source). ${ }^{7}$ The named female power or divine personality, who brings us back to the theme of this paper, is called Mokoš'. Here we probably have a representative of that omnifunctional goddess well known elsewhere in the I-E world, comparable to the great Iranian Anahita, "moist, heroic, immaculate" and more immediately cognate to the Russian folklore figure Mokoš', "moist mother earth" (Puhvel 1987: 165ff.), who is the divine sustainer of all things - fertility, sexuality, and continuance personified. But the Povest' also provides us with another important figure, a female regent-ruler in Kiev who brilliantly stars in her own drama, a drama which we might call "The Revenge of Olga."

As history (or history according to the chronicle) has it, in $945 \mathrm{AD}$ the Grand Prince Igor' of Kiev was killed by the neighboring Derevlians (RPC 78; PVL 62). Olga, Igor's widow and mother of his heir Sviatoslav, assumed the regency, and soon received an embassy from these same Derevlians offering her a new husband, one of their own princes, named Mal. ${ }^{8}$ Olga cozzened the envoys, convincing them that to uphold their dignity they, in their own boat, should be carried by the Kievans right up to the city's citadel. And so they were, "puffed up with pride" ( $P V L$ 64) whereupon they were summarily dumped, boat and all, into a great ditch, and subsequently buried alive. A second embassy, made up of Derevlians' chief men, was then invited by Olga to Kiev and these unfortunates were trapped in a bathhouse and burned to death (RPC 79-80; PVL 65). Finally Olga rode into Derevlian territory with a small retinue, seeking out her husband's grave, as she said, and asking the Derevlians (who evidently were extraordinarily slow to learn that the widow Olga was not a forgiving person) to provide the mead for a funeral feast. At this feast the Derevlians drank freely, and when they were drunk Olga's army came up and killed the lot of them, to the number, the chronicle attests, of five thousand.

Not content with these three acts of vengeance, by earth, fire, and (fire) water, Olga and her army then invested Iskorosten', the city near where Igor' had been killed, and eventually destroyed it using the good old legendary device of releasing "sparrows and pigeons" she had received from the residents as a (suspicioualy mild) tribute. Each bird was equipped with a bit of burning tow attached to its legs; the birds of course returned to their nests and cotes in the city, which promptly took fire and burned to the ground (RPC 81, PVL 68-69).

\footnotetext{
${ }^{7}$ In fact Volos appears in a grouping that certainly can be interpreted as having trifunctional significance: in ratifying the treaty of $912 \mathrm{AD}$ with the Byzantines the Rus' "swore by their weapons and by their god Perun, as well as by Volos, the god of cattle" (RPC 65; PVL 32).

${ }^{8} R P C 238$ (fn. 55) discusses the possible etymology of this name.
} 
Olga had other adventures as given in the Povest', including (during her visit to Constantinople) an offer of marriage by the Byzantine Emperor (which never took place) and her Christian baptism (which evidently did). Her given baptismal name was Helena, and thus she was connected to the primary act of imperial foundation connected with the numinous name of Constantine the Great (see Miller 2000). In fact Olga can be shown to be seen and presented as an ominfunctional, hyperpotent feminine figure, possessed of maternal powers, of warriorlike (or war-queenly) abilities, and finally as she was, again according to the Povest', "wiser than all the men" (RPC 111; PVL 137). ${ }^{9}$ More importantly, she even has at least some of the nature of a "grantor of sovereignty," as this is traceable in the effort by the Derevlians to have he marry their mysterious Prince Mal and this same transcultural and perdurable theme must even be extended, in her tale, to the fictitious offer of marriage by the Byzantine emperor. The sovereignty of Kiev, evidently, was in her gift. ${ }^{10}$

More recent Slavic or Russian history would see nothing quite like Olga, though we ought to note the singular $17^{\text {th }}$ century figure of Sophia Alexeevna, who also held the regency, and who deftly used religious tropisms associated with her name - "Sophia, the Wisdom of God" - as well as an appeal to a medieval Russian cult dedicated to this symbolic figure in order to bolster her secular power amidst the toils of a "patriarchal" political system (see Zelensky 1992: 192-211). Nor, of course, should we forget Catherine the Great and her own real power - and her questionable (and legendary) doings. ${ }^{11}$ But Princess Olga is our most potent example of an historical figure inflated with the breath of mythical signs and symbols, all intermixed with reverberations from, I contend, the Indo-European inheritance. Olga, it seems to me, is encased in and surrounded by evidences both of 'history,' and of 'story' (that is, of themes resonating in myth and mythopoeia).

\section{Conclusion}

Obviously within our two target areas feminine potencies, imagined and real, are able to overleap the bounds of patriarchy and establish themselves, if not as perfectly independent, then as vitally important players in the games and schemes of power. ${ }^{12}$ The 'horse-goddess' theme, so important in the Celtic West, does not reach to the Slavic lands; I might suggest that here the influence of Gimbutas's theorized Old Europe, with its singular lack of hippomorphic divinities, might be more powerful in the East of the European subcontinent. But that is still to debate, and I don't doubt will be debated.

\footnotetext{
${ }^{9}$ In Constantinople, her reception was included in the De Ceremoniis (DC 594-598) where the various contours and devices of Byzantine ceremonial were specifically tailored to fit a female ruler, thus confirming one of Jonathan Z. Smith's important theories concerning the flexibility and inventiveness of ritual, see Smith 1976/1982.

${ }^{10}$ I am grateful to John Carey for his suggestion that the British queen Boudicca also was a revengeseeking woman ruler.

${ }^{11}$ I cannot avoid at least setting into a footnote the scabrous legend of the sexually insatiable empress copulating with s stallion - bruited at home and abroad as a sign of her decadence, but also precisely reflective of the ritual of sovereignty noted above by Sterckx, of Queen and Stallion.

${ }^{12}$ I can only note here the possibility of Norse ("Varangian") influence in Kiev; the North Germanic prominence of female deities and of an actual 'social' balance between the sexes - as in the case of divorce - is fairly well known. Yet Olga seem to me an acceptably - finally - Slavic instance of female potency in fact and in story or fiction.
} 


\section{ABBREVIATIONS}

$\boldsymbol{B G}=$ Julius C. Caesar, De Bello Gallico. The Gallic Wars, transl. by H. J. Edwards, Cambridge, MA/London: Harvard University Press/Wm. Heinemann, 1979.

DC = De Ceremoniis Aulae Byzantinae, CSHB, ed. B. G. Niebuhr, Bonn: Weber, 1829.

$\boldsymbol{P V L}=$ Shakhmatov, A. А.. 1916/1969, Повесть временных лет [Russian Primary Chronicle]. Petrograd: Tipograofiya Orlova/ Slavistic Printings and Reprintings, ed. C. H. van Schooneveld. The Hague/Paris: Mouton.

$\boldsymbol{R P C}=$ Cross, S. H. \& Sherbowitz-Wetzor, O. P, eds. \& transl., The Russian Primary Chronicle. Laurentian Text, Cambridge, MA/The Medieval Academy of America.

\section{BIBLIOGRAPHY}

Allen, N. J., 1987, 'The Ideology of the Indo-Europeans: Dumézil's Theory and the Idea of a Fourth Function,' International Journal of Moral and Social Studies, vol. 2, no. 1, 23-39.

Allen, N. J., 1993, 'Debating Dumézil: Recent Studies in Comparative Mythology,' JASO 34/2, 119-131.

Dexter, M. R., 1990, Whence the Goddess. A Source Book, The Athenae Series, New York/Oxford: MacMillan/Pergamon.

Ford, P. K., ed. \& transl., 1977, The Mabinogi and Other Medieval Welsh Tales, Berkeley/Los Angeles/London: The University of California Press.

Gimbutas, M., 1974/1982, The Gods and Goddesses of Old Europe. Myths and Cult Images, Berkeley/Los Angeles: The University of California Press.

Green, M., 1986, The Gods of the Celts, Godalming, Surrey: Brawley.

Herbert, M., 1992, 'Goddess and King: The Sacred Marriage in Early Ireland,' in: Women and Sovereignty $=$ Cosmos 7, 264-275.

Lyle, E., 1982, 'Dumézil's Three Functions and Indo-European Cosmic Structure,' History of Religions 22.1, 25-44.

Maier, Bernhard, 1997, Dictionary of Celtic Religion and Culture. Transl. by C. Edwards, Woodbridge, Suffolk/Rochester, NY: Boydell \& Brewer.

Mikhailova, T. А., 2005, 'Ирландская банши и русская русалка' ['Irish bean sí and Russian rusalka,' in T. Mikhailova, ed., Мифологема женщины-судьбы [The mythologem of woman-fate]. Moskva: Indrik, 228-47.

Miller, D. A., 1999, 'Playing (with) the Numbers: Variations on a Dumézilian Theme,' JASO 30/1: 35-50.

Miller, D. A., 2000, 'The Second Founder and the Fourth Function: Constantine After Romulus,' The Mankind Quarterly XL/3: 327-336.

Miller, D. A., 2006, 'Talking Heads, Taking Heads: Somatic Signs and the IndoEuropean Functions,' Anthropology of the Indo-European World and Material Culture. Proceedings of th 5th International Colloquium of Anthropology of the Indo-European World and Comparative Mythology = Archaeolingua, Budapest, 275-283.

Mommsen, T., 1887, Provinces of the Roman Empire, I, New York: Charles Scrobner's Sons. 
Ó Cathasaigh, T., 1977, The Heroic Biography of Cormac mac Airt, Dublin: DIAS.

Petit, P., 1976, Pax Romana. Transl. by J. Willis, Berkeley/Los Angeles: University of California Press.

Puhvel, J., 1955, 'Vedic aśvamedha and Gaulish EPOMEDVOS,' Language 31: 353354.

Puhvel, J., 1970, 'Aspects of Equine Functionality,' in: J. Puhvel, ed., Myth and Law Among the Indo-Europeans: Studies in Indo-European Comparative Mythology, Berkeley/Los Angeles: University of Califronia Press: 159-172.

Puhvel, J., 1987, Comparative Mythology, Berkeley/London/Los Angeles: University of California Press.

Rowell, S. C., 1994, Lithuania Ascending. A Pagan Empire Within East-Central Europe, 1295-1345, Cambridge Studies in Medieval Life and Thought, 4th Series. Cambridge: Cambridge University Press.

Smith, J. Z., 1976, 'A Pearl of Great Price and a Cargo of Yams,' in History of Religions 16: $1-13$.

Sterckx, C., 1994, Les dieux protéens des celtes et des indo-européens. Mémoirs de la Société Belge d'Etudes Celtiques, IV. Société Belge d'Etudes Celtiques/Belgische Genootschap voor Keltische Studies, Brussels.

Sterckx, C., 2004, 'Hierogamie ou pornographie?', Bulletin d'Information de la Société Belge d'Etudes Celtiques/Niewesbericht van den Belisgische Genootschap voor Keltische Studies. XVIIIe année/jaar, No. 143 (November/novembre): 52-57.

Tacitus, 1999, Annales = The Annals. Transl. by J. Jackson. Loeb Classical Library. Cambridge, MA/London: Harvard University Press.

Táin Bó Cúalnge, 1984, Táin Bó Cúalnge, from the Book of Leinster, ed. C. O'Rahilly, Dublin: DIAS.

Toporov, V. N., 1961, ‘Фрагмент славянской мифологии' ['A fragment from Slavic mythology'], Akademiya Nauk SSSR, Institut Slavyanovedeniya, Kratkiye soobshcheniya 30: 14-32.

Zelensky, E. K., 1992, 'Sophia the Wisdom of God': The Formation of Religious Imagery during the Regency of Sofia Alexeevna of Muscovy,' in: Women and Sovereignty $=$ Cosmos 7: 192-211. 